\title{
PERAN IMIGRASI TERHADAP FENOMENA SOSIAL ORANG ASING YANG BEKERJA TIDAK SESUAI ATURAN DI INDONESIA
}

\section{THE ROLE OF IMMIGRATION AGAINST THE SOCIAL PHENOMENA OF NON- PROCEDURAL FOREIGN WORKERS IN INDONESIA}

\author{
Penny Naluria Utami, Tony Yuri Rahmanto \\ Badan Penelitian dan Pengembangan Hukum dan HAM, Kementerian Hukum dan HAM RI \\ Jl. H.R. Rasuna Said Kavling 4-5, Jakarta Selatan, DKI Jakarta \\ penny_utami@yahoo.com,tonyscooterist@gmail.com
}

\begin{abstract}
ABSTRAK
Sejak diberlakukannya Kebijakan Bebas Visa Kunjungan bagi Orang Asing yang awalnya untuk meningkatkan inventasi di Indonesia rupanya dimanfaatkan pula oleh oknum orang asing lainnya untuk bekerja di Indonesia tanpa melalui prosedur resmi sehingga tidak hanya menjadi masalah pada tugas dan fungsi Direktorat Jenderal Imigrasi sebagai leading sector dalam penanganan orang asing namun berdampak pula pada Warga Negara Indonesia yang akan mencari kerja di Indonesia. Tulisan ini bertujuan mengetahui penyebab Orang Asing bekerja secara nonprosedural di Indonesia dan upaya Petugas Imigrasi terhadap keberadaan dan kegiatan Warga Negara Asing yang bekerja secara nonprosedural di Indonesia. Penelitian ini bersifat deskriptif-analitis dengan menggunakan metode kualitatif dan kuantitatif. Hasil penelitian menunjukkan bahwa keberadaan regulasi terutama Kebijakan Bebas Visa Kunjungan (BVK) menjadi faktor dominan maraknya Orang Asing bekerja secara nonprosedural di Indonesia sehingga perlu dilakukan evaluasi terhadap aturan tersebut secara menyeluruh dengan melibatkan seluruh pemangku kepentingan terkait. Peran vital Direktorat Jenderal Imigrasi dalam mengelola perlintasan manusia baik ke dalam maupun keluar Indonesia perlu didukung oleh penguatan sumber daya manusia serta sarana-prasarana yang memadai. Paralel dengan hal tersebut, peran vital Kementerian Ketenagakerjaan dalam melakukan pengawasan dan penindakan terhadap perusahaanpun harus didukung dengan penguatan yang sama, terutama bagi petugas pengawas ketenagakerjaan. Penguatan payung hukum dan kelembagaan Tim Pengawasan Orang Asing (Timpora) juga menjadi salah satu bahan masukan yang penting mengingat pengawasan yang efektif terhadap orang asing di Indonesia mensyaratkan satu pendekatan yang holistik dan kerjasama yang padu antar pemangku kepentingan didalamnya.
\end{abstract}

Kata Kunci: Imigrasi, Orang Asing, Bekerja, Tidak Resmi

\begin{abstract}
Since the entry into force of the Visa Free Visit Policy for Foreigners, which was initially used to increase inventory in Indonesia, it seems that other foreigners also used to work in Indonesia without going through official procedures so that it is not only a problem in the duties and functions of the Directorate General of Immigration as a leading sector in handling people foreigners but also has an impact on Indonesian citizens who will find work in Indonesia. This paper aims to find out the causes of foreigners working non-procedural in Indonesia and the efforts of the Immigration Officers for the presence and activities of Foreign Citizens working non-procedural in Indonesia. This research is descriptive-analytical using qualitative and quantitative methods. The results showed that the existence of regulations, especially the Visa Free Visit Policy, became the dominant factor in the rise of Foreigners working non-procedural in Indonesia, so that an overall evaluation of these rules was needed by involving all relevant stakeholders. The vital role of the Directorate General of Immigration in managing human crossings both into and out of Indonesia needs to be supported by strengthening human resources and adequate infrastructure. Parallel to this, the vital role of the Ministry of Manpower in carrying out supervision and enforcement of companies must also be supported by the same reinforcement, especially for labor inspection officers. Strengthening the legal and institutional umbrella of the Foreigners Oversight Team (Timpora) is also one of the important inputs, considering that effective supervision of foreigners in Indonesia requires a holistic approach and coherent cooperation among stakeholders therein.
\end{abstract}

Keywords: Immigration, Foreigners, Work, Non Procedural 


\section{PENDAHULUAN}

Perpindahan seseorang dari satu negara ke negara lainnya bukan lagi menjadi hal yang istimewa saat ini, karena dengan adanya kemajuan teknologi dan komunikasi membuat proses tersebut menjadi lebih mudah dari sebelumnya. Keinginan untuk mendapatkan kehidupan yang lebih baik dirasakan menjadi faktor dominan pada setiap orang untuk melakukan migrasi menuju negara lain.

Buckley dalam (Schwartz, 1998) menyatakan, alasan lain yang mempengaruhi keinginan untuk melakukan imigrasi terpusat pada isu-isu mengenai keamanan, kesejahteraan, dan kepuasan terhadap satu kelompok atau lebih. Perasaan tidak puas, kebosanan, dan kondisi yang tidak nyaman di negara asal mereka menjadi faktor pendorong mereka untuk melakukan migrasi. Lebih lanjut (Schwartz, 1998) mengatakan keuntungan yang mungkin didapatkan dalam melakukan imigrasi dapat dikategorikan menjadi dua hal, yaitu (a) Pasar kerja yang menyediakan banyak kesempatan dan keuntungan yang lebih baik; dan (b) Negara tujuan lebih menarik karena pertimbangan kondisi fisik yang lebih aman, misalnya adanya penyatuan hubungan keluarga dan perlindungan hukum yang pasti terhadap imigran yang mencari suaka (pengungsian).

Senada dengan pendapat sebelumnya, (Iman, 2014) mengatakan, era globalisasi sering diasumsikan sebagai universalisme tanpa batas sehingga setiap orang dapat berinteraksi satu sama lain secara cepat dan mudah meski berbeda tempat dan negara, seiring kemajuan teknologi transportasi. Implikasinya adalah pergerakan manusia melintas batas antar negara secara mudah sehingga keterbukaan akses dan kemudahan inilah yang menjadikan paspor sebagai sebuah kebutuhan dasar bagi warga negara Indonesia yang ingin melakukan perlintasan ke luar negeri.

Namun demikian, perpindahan orang dari satu negara ke negara lain rupanya tidak serta merta memberikan keuntungan yang positif bagi negara tujuan para imigran atau Orang Asing tersebut, akan tetapi juga dikhawatirkan memberikan pengaruh negatif bagi negara yang dituju tersebut.

Dapat dipahami bahwa faktor dominan dari para imigran atau orang asing datang ke negara lain disebabkan karena faktor ekonomi, sehingga hampir sebagian besar para imigran atau orang asing tersebut pindah ke negara tujuan adalah untuk mencari pekerjaan yang lebih baik dari negara asalnya. (Boswell, 2009) berpendapat bahwa faktor ekonomi merupakan faktor terbesar yang menjadi dasar seseorang melakukan migrasi adalah majunya perkembangan ekonomi di negara lain, serta negara-negara berkembang membutuhkan tenaga ahli yang berpengalaman untuk membantu meningkatkan kesejahteraannya. Selain itu, para imigran dianggap memiliki pengalaman dan keahlian yang dibutuhkan oleh negara berkembang untuk membantu memperkaya pengetahuan dan ekonomi suatu negara. Akan tetapi setiap negara tujuan juga perlu menseleksi para imigran atau orang asing yang akan datang ke negaranya, karena dikhawatirkan tujuan utama kedatangan mereka bukan untuk bekerja melainkan untuk melakukan kegiatan pelanggaran ataupun kejahatan seperti perdagangan narkotika antarnegara, aksi-aksi terorisme yang mengancam keamanan dan ketertiban dunia, perdagangan manusia (human trafficking), penyelundupan manusia (people smuggling), pencucian uang (money laundring), imigran gelap, perdagangan senjata dan lain sebagainya.

Saat ini, Negara Indonesia menjadi salah satu tujuan utama para imigran atau WNA untuk bekerja. Hal tersebut disebabkan karena lokasinya yang strategis, yakni terletak diantara dua benua dan dua samudra dan memiliki hubungan sejarah yang kuat dalam proses perpindahan warga negara asing, terutama negara Timur tengah, Asia, dan Afrika yang mendukung Indonesia menjadi sebuah negara transit migrasi yang strategis. Selain itu, Negara Indonesia juga memiliki beberapa kebijakan yang diterbitkan oleh Pemerintah Indonesia yang salah satunya adalah Kebijakan Bebas Visa Kunjungan 169 Negara. Kebijakan ini memungkinkan para imigran atau WNA dari 169 Negara yang tercantum dalam kebijakan tersebut dapat dengan bebas untuk masuk ke Indonesia tanpa dikenakan Visa. Sedangkan dari sisi ketenagakerjaan, kedatangan TKA diharapkan untuk mengatasi krisis tenaga kerja yang terampil. Oleh karena itu Negara Indonesia memberikan kesempatan kerja kepada orang asing yang memiliki kualifikasi yang cocok dengan persyaratan yang telah disahkan dalam undang-undang ketenagakerjaan serta, pemerintah melegalkan setiap perusahaan untuk merekrut atau memiliki tenaga kerja asing sebagai karyawan dengan persyaratan tertentu sesuai dengan undang-undang ketenagakerjaan. 
Namun demikian berkaitan dengan imigran atau orang asing yang bekerja di Indonesia rupanya tidak terlepas dari berbagai permasalahan. Hal yang demikian dapat terlihat pada implementasi di lapangan melalui pemberitaan beberapa media, diantaranya adalah pernyataan yang disampaikan oleh Wakil Ketua Ombudsman RI, Lely Pelitasari Soebekty dalam (Putra, 2018) yang menyatakan bahwa adanya temuan tenaga kerja asing (TKA) ilegal yang masuk ke Kendari, Sulawesi Tenggara. Masuknya TKA tersebut menyalahi aturan dengan memanfaatkan visa kunjungan-untuk, tetapi dipakai untuk bekerja. Dalam sehari $70 \%$ penumpang penerbangan menuju Kendari merupakan WNA asal Tiongkok yang menggunakan visa kunjungan wisata, sedangkan sisanya melalui jalur laut. Beberapa contoh kasus lain disampaikan oleh (Ginting, 2018) yang menyatakan bahwa Tim Pengawas Orang Asing (selanjutnya disebut Timpora) Kantor Imigrasi Kelas I Tangerang mencokok 25 WNA yang bekerja di PT Smartfren Telecom, kawasan BSD, Kota Tangerang Selatan. WNA yang tidak memiliki legalitas sebagai pekerja ini merupakan warga China dan India yang telah bekerja hampir 4 tahun. Para pekerja asing yang terjaring oleh pihaknya ini menyalahi prosedur keimigrasiaan berupa tidak memiliki paspor, izin tinggal berlebih (overstay), sampai penyalahgunaan visa kunjungan.

Kemudian dari hasil kunjungan kerja Komisi IX DPR RI ke Bali yang dikutip dari (Rahmat, 2016) menjelaskan bahwa ditemukan adanya sejumlah pelanggaran yang dilakukan oleh beberapa perusahaan di Bali yang menyalahgunakan Izin Mempekerjakan Tenaga Kerja Asing (IMTA) sehingga tidak sesuai dengan realitas pekerjaan yang dikerjakan. Misalnya, di dalam IMTA disebutkan bahwa keahliannya accounting tetapi bekerja pada bagian personalia. Ada yang di dalam IMTA bekerja sebagai mekanik, namun di lapangan bekerja sebagai buruh kasar. Ada juga fakta bahwa para TKA itu tidak bisa berbahasa Indonesia sehingga pengumuman dan instruksi di tempat kerja menggunakan bahasa China. Hal ini tentu menyulitkan tenaga kerja lokal yang hanya mampu berbahasa Indonesia. Kendala bahasa ini tentu mengakibatkan adanya kesulitan transfer of knowledge, terutama dari TKA yang sangat ahli dalam bidangnya.

Sebagai informasi, berdasarkan data dari Direktur Jenderal Pembinaan Penempatan Tenaga Kerja dan Perluasan Kesempatan Kerja
Kementerian Ketenagakerjaan Maruli Apul Hasoloan dalam (Djumena, 2019) bahwa jumlah TKA sampai akhir 2018 lalu mencapai 95.335 orang. Angka ini meningkat 10,88 persen dibanding sepanjang 2017 lalu yang mencapai 85.974 orang. Dari jumlah tersebut jumlah tenaga asing yang banyak datang ke Indonesia adalah dari China (32.000), Jepang (13.897), Korea (9.686), India (6.895) dan Malaysia (4.667). Sementara menurut (Petriella, 2019), Jumlah penggunaan tenaga kerja asing pada 2019 diperkirakan mengalami kenaikan sebesar $20 \%$ dari total tenaga kerja asing tahun lalu yang sebanyak 95.335 orang. Kenaikan ini diindikasikan sebagai akibat diterbitkannya Keputusan Menteri Ketenagakerjaan RI Nomor 228 Tahun 2019.

Merujuk beberapa permasalahan yang dikemukakan sebelumnya, permasalahan TKA yang bekerja di Indonesia rupanya menjadi permasalahan serius yang perlu mendapatkan penyelesaian dengan segera. Namun demikian, penyelesaian tersebut rupanya tidak dapat diselesaikan melalui satu aspek saja yaitu aspek ketenagakerjaan. Pernyataan sebelumnya dapat dipahami bahwa banyak aspek dan banyak pendekatan yang terlibat dalam menangani Orang Asing yang bekerja di Indonesia. Salah satu yang juga memiliki andil besar terhadap tenaga kerja asing adalah aspek keimigrasian, karena tugas dan fungsi dari keimigrasian adalah sebagai penjaga pintu gerbang negara yang mengatur lalu lintas orang asing dan melakukan pengawasan terhadap keberadaan orang asing di wilayah Indonesia.

Jika melihat data perlintasan manusia pada periode Januari-Juni 2017 yang dikutip dari (Belarminus, 2017), dapat diketahui bahwa Ditjen Imigrasi telah melayani perlintasan orang sebanyak 19.089.288 orang. Angka ini terdiri dari 8.765.487 WNI dan 10.323.801 WNA. Angka ini terdiri dari 8.765.487 WNI dan 10.323.801 WNA. Sementara pada tahun 2018 yang dikutip dari (Laoly, 2018), data perlintasan manusia yang keluar wilayah Indonesia adalah sebanyak 20.614.717 orang dan yang masuk wilayah Indonesia sebanyak 19.921 .016 orang. Melihat data sebelumnya maka selama satu tahun terdapat peningkatan sejumlah 9.597.215 orang WNA yang masuk ke Indonesia.

Sejak diberlakukannya Peraturan Presiden Nomor 21 Tahun 2016 tentang Bebas Visa Kunjungan (Perpres 21/2016 BVK) yang dirilis oleh Direktorat Jenderal Imigrasi dari kurun waktu Januari 2016 hingga Desember tahun 
2016 dan Tahun 2017 (Januari-Februari) yaitu dari 6 (enam) jenis Tindakan Administratif Keimigrasian (TAK), tiga diantaranya adalah 1) deportasi menduduki urutan teratas yaitu 4.562 kasus; 2) kasus pencegahan/penangkalan sebanyak 2.041 kasus, dan 3) WNA yang mendapatkan detensi sebanyak 1.908 kasus. Sementara jika didasarkan pada negara asalnya, Negara Tiongkok menduduki urutan pertama terkait TAK. yaitu sebesar 1.849; kemudian disusul negara Afghanistan sebanyak 664 kasus. (T.A. Nugroho, 2018). Hal tersebut diindikasikan karena terbitnya Perpres 21/2016 tentang Kebijakan Bebas Visa Kunjungan, yang menyebabkan terjadi peningkatan baik dari sisi jumlah perlintasan WNA maupun jumlah peningkatan TAK.

Secara khusus, dalam konteks perwujudan nilai-nilai strategis ditegaskan pada poin menimbang Undang-Undang Keimigrasian yang menyatakan bahwa "Keimigrasian merupakan bagian dari perwujudan pelaksanaan penegakan kedaulatan atas Wilayah Indonesia dalam rangka menjaga ketertiban kehidupan berbangsa dan bernegara menuju masyarakat yang adil dan makmur berdasarkan Pancasila dan Undang-Undang Dasar Negara Republik Indonesia Tahun 1945". Dari poin menimbang sebelumnya maka muncul prinsip dasar dari Undang-Undang Keimigrasian diantaranya adalah Indonesia bukan Negara Imigran (Non Immigrant Country); kebijaksanaan berdasarkan sistem penyaringan (Selective Policy); setiap orang yang akan masuk atau keluar wilayah Indonesia harus melalui Tempat Pemeriksaan Imigrasi (selanjutnya disebut TPI), setiap Warga Negara Indonesia atau asing yang masuk/keluar wilayah Indonesia harus memiliki surat perjalanan (paspor) yang sah dan masih berlaku dan setiap orang asing yang memasuki wilayah Indonesia diharuskan memiliki visa kecuali negara-negara yang dibebaskan dari keharusan memiliki visa.

Dalam kaitannya dengan orang asing yang masuk ke wilayah Indonesia seyogyanya haruslah orang-orang yang membawa manfaat bagi bangsa dan Negara Republik Indonesia serta keberadaannya tidak menimbulkan gangguan terhadap ketertiban dan keamanan nasional. Hal yang demikian tertuang dalam Pasal 43 Ayat (2) poin a Undang-Undang Keimigrasian yang menyatakan bahwa "Orang Asing yang dibebaskan dari kewajiban memiliki Visa sebagaimana dimaksud pada ayat (1) adalah: a. warga negara dari negara tertentu yang ditetapkan berdasarkan Peraturan Presiden dengan memperhatikan asas timbal balik dan asas manfaat".

Kemudian pada sisi ketenagakerjaan, maraknya WNA yang menyalahgunakan izin untuk bekerja tersebut, rupanya semakin mempersempit ruang bagi tenaga kerja lokal untuk mendapat kesempatan yang sama untuk memperoleh pekerjaan. Ombudsman Republik Indonesia (ORI) menemukan permasalahan dalam penempatan dan pengawasan Tenaga Kerja Asing (TKA) di Indonesia. Temuan tersebut berdasarkan hasil investigasi Ombudsman di tujuh provinsi, yaitu DKI Jakarta, Jawa Barat, Banten Sulawesi Tenggara, Papua Barat, Sumatera Utara dan juga Kepulauan Riau. Investigasi itu berlangsung pada Juni-Desember 2017. Komisioner Ombudsman, Laode Ida dalam (Mamduh, 2018) menjelaskan, pada aspek penempatan tenaga kerja asing, belum dilakukan integrasi data antara pemerintah pusat dan daerah. Data yang dimaksud Ombudsman meliputi jumlah TKA, persebaran dan alur keluar-masuknya para pekerja. Ombudsman juga menemukan bahwa banyak TKA justru bekerja di level terbawah, yaitu kuli kasar. Ini memberikan indikasi kalau perusahaan pengguna TKA berbohong pada pemegang otoritas dan lemahnya pengawasan dari pihak pemerintah.

Hal senada juga disampaikan oleh (A. Nugroho, 2018) yang berpendapat bahwa perdebatan semakin memanas setelah pemerintah mengeluarkan Perpres Nomor 20 Tahun 2018 yang membahas tentang TKA. Pihak yang kontra menganggap kebijakan tersebut menjadi karpet merah masuknya TKA ke Indonesia. Sebagian pihak menganggap masuknya TKA ke Indonesia berbahaya bagi kondisi ketenagakerjaan tanah air. Argumentasi utamanya adalah bahwa di Indonesia berdasarkan data Badan Pusat Statistik (BPS) dalam (Andreas, 2018) menyatakan jumlah pengangguran masih tergolong tinggi lebih dari 7 juta jiwa, sehingga masuknya TKA dapat memperuncing persaingan dalam mendapatkan pekerjaan. Dalam peringatan Mayday 2018, ada beberapa serikat buruh yang menganggap TKA sebagai isu utama. (A. Nugroho, 2018)

Melihat latar belakang yang telah dipaparkan sebelumnya maka tulisan ini difokuskan kepada gambaran permasalahan dan pencegahan Warga Negara Asing yang Bekerja Secara Non Prosedural di Indonesia yang saat ini yang dinilai menjadi isu sosial khususnya 
terhadap kesejahteraan masyarakat Indonesia sendiri. Atas dasar hal tersebut peneliti ingin menggali lebih dalam terhadap faktor dominan penyebab orang asing yang bekerja di Indonesia secara nonprosedural.

\section{METODE PENELITIAN}

Penelitian ini merupakan penelitian yuridis empiris dengan pendekatan mix methods (metode campuran) kualitatif dan kuantitatif yang bertujuan untuk mengukap fakta, keadaan yang terjadi saat penelitian berjalan dan menyuguhkan data ataupun fakta apa adanya.

(Muhammad, 2004) berpendapat bahwa penelitian yuridis empiris merupakan penelitian hukum mengenai pemberlakuan atau implementasi ketentuan hukum normatif secara in action pada setiap peristiwa hukum tertentu yang terjadi dalam masyarakat. Adapun ruang lingkup penelitian ini dibatasi pada penyebab orang asing bekerja secara nonprocedural di Indonesia, serta pencegahannya melalui pendekatan keimigrasian yang juga berfungsi sebagai kontrol sosial.

Pengumpulan data dilakukan dengan menggunakan sumber data primer (field research) berupa data yang diperoleh langsung dari responden narasumber dan informan, sedangkan sumber data sekunder dikumpulkan berdasarkan penelusuran literatur (library research) untuk kemudian dianalisis secara kuantitatif dan kualitatif. Lokasi penelitian dilaksanakan di Provinsi Kepulauan Riau, Kalimantan Barat, Sulawesi Tenggara, Jawa Barat dan DKI Jakarta. Total jumlah responden dalam penelitian ini sebanyak 125 orang yang terdiri dari pejabat/pegawai di Kantor Imigrasi Kementerian Hukum dan Hak Asasi Manusia. Sementara informan berasal dari pejabat/pegawai di Kantor Wilayah Kementerian Hukum dan Hak Asasi Manusia, pejabat/pegawai di Kantor Imigrasi Kementerian Hukum dan Hak Asasi Manusia, pejabat/pegawai pada Kementerian Tenaga Kerja/Dinas Tenaga Kerja Provinsi/Kabupaten/Kota, Ombudsman Republik Indonesia dan perwakilannya di daerah serta akademisi dari sejumlah universitas di Indonesia sesuai lokasi penelitian.

Teknik analisis data yang digunakan dalam penelitian ini terdapat dua teknik analisis, pertama menggunakan analisis deskriptif kualitatif yang menurut (Moleong, 2006) merupakan analisis yang menggambarkan keadaan atau suatu fenomena dengan kata-kata atau kalimat kemudian dipisahkan menurut kategorinya untuk memperoleh kesimpulan. Adapun langkah-langkah yang dilakukan dalam melakukan analisis data adalah dengan membuat hipotesis awal berdasarkan latar belakang dan rumusan masalah yang diantaranya: (i) Keberadaan celah dalam regulasi/kebijakan keimigrasian dan ketenagakerjaan berpeluang dimanfaatkan oleh Orang Asing untuk bekerja secara nonprosedural di Indonesia; (ii) Minimnya Sumber Daya Manusia pada unit pelaksana teknis (UPT) Imigrasi dan Ketenagakerjaan khususnya dalam bidang pengawasan dan penindakan menjadi penyebab Orang Asing bekerja secara nonprosedural di Indonesia; (iii) Minimnya Sarana dan Prasarana pada UPT Imigrasi dan Ketenagakerjaan khususnya dalam bidang pengawasan dan penindakan menjadi penyebab Orang Asing bekerja secara nonprosedural di Indonesia dan (iv) Upaya Petugas Imigrasi dalam melakukan pengawasan dan penindakan terhadap keberadaan dan kegiatan Orang Asing di Indonesia masih belum optimal.

Selanjutnya, peneliti melakukan analisis dengan pendekatan multidimensional untuk mendapatkan gambaran utuh dan komprehensif difokuskan melalui pendekatan hukum dan pendekatan keimigrasian. Dalam mendeskripsikan gambaran mengenai potensi permasalahan maka digunakan Pendekatan hukum yang menggunakan perspektif Teori "Model" Sistem Hukum (Friedman, 1975), yang menyatakan bahwa berhasil atau tidaknya Penegakan Hukum bergantung pada tiga unsur sistem hukum, yaitu: (a) Substansi Hukum (legal substance) bisa dikatakan sebagai norma, aturan, dan perilaku nyata manusia yang berada pada sistem itu, artinya aturan-aturan yang dibuat oleh pembuat kebijakan dijadikan pedoman bagi pelaksana dan masyarakat dalam penerapannya namun demikian terdapat penekanan bahwa suatu hukum akan dibuat jika terdapat peristiwa yang menyebabkan kerugian bagi masyarakat baik materiil maupun immaterial terlebih dahulu; (b) Struktur Hukum (legal structure) dan Struktur Hukum/Pranata Hukum. Struktur hukum (legal structure) yaitu kerangka bentuk yang permanen dari sistem hukum yang menjaga proses tetap berada di dalam batas-batasnya. Karena Hukum tidak dapat berjalan atau tegak bila tidak ada aparat penegak hukum yang kredibilitas, kompoten dan independen; dan (c) Budaya Hukum (legal 
culture), dimaknai sebagai suasana pikiran sosial dan kekuatan sosial yang menentukan bagaimana hukum digunakan, dihindari, atau disalahgunakan.

Sementara pendekatan Keimigrasian menggunakan perspektif Teori Implementasi Kebijakan George Edward III dalam (Agustino, 2008) yang menyatakan bahwa dalam pendekatan teori ini terdapat 4 (empat) variabel yang mempengaruhi keberhasilan implementasi suatu kebijakan, yaitu:

1. Komunikasi; sangat menentukan keberhasilan pencapaian tujuan dari implementasi kebijakan publik. Pengetahuan atas apa yang akan mereka kerjakan dapat berjalan apabila komunikasi berjalan dengan baik, sehingga setiap keputusan kebijakan dan peraturan impelementasi harus ditansmisikan (atau dikomunikasikan) kepada bagian personalia yang tepat. Terdapat 3 (tiga) indikator yang dapat dipakai dalam mengukur keberhasilan variabel komunikasi yaitu: (a) transmisi; penyaluran komunikasi yang baik akan dapat menghasilkan suatu implementasi yang baik pula, agar tidak terjadi adanya salah pengertian (misscommunication); (b) kejelasan; komunikasi yang diterima oleh para pelaksana kebijakan (street-levelbureuarats) haruslah jelas dan tidak membingungkan (tidak ambigu/mendua) agar tidak terjadi penyelewengan dalam tujuan yang hendak dicapai oleh kebijakan yang telah ditetapkan; dan (c) konsistensi; perintah yang diberikan dalam melaksanakan suatu komunikasi haruslah konsisten dan jelas untuk diterapkan atau dijalankan agar tidak menimbulkan kebingungan bagi pelaksana di lapangan.

2. Sumber Daya; merupakan hal penting lainnya dalam mengimplementasikan kebijakan. Indikator sumber daya terdiri dari beberapa elemen, yaitu: (a) staf; sumber daya utama dalam implementasi kebijakan adalah staf. Kegagalan yang sering terjadi dalam implementasi kebijakan salah satunya disebabkan oleh jumlah staf yang tidak mencukupi, memadai, ataupun tidak kompeten di bidangnya. Penambahan jumlah staf dan implementor saja tidak cukup, tetapi diperlukan juga kecukupan staf dengan keahlian dan kemampuan yang diperlukan (kompeten dan kapabel) dalam mengimplementasikan kebijakan atau melaksanakan tugas yang diinginkan oleh kebijakan itu sendiri; (b) informasi; dalam implementasi kebijakan, informasi mempunyai 2 (dua) bentuk, yaitu: pertama informasi yang berhubungan dengan cara melaksanakan kebijakan. Implementor harus mengetahui apa yang harus mereka lakukan saat mereka diberi perintah. Kedua, informasi mengenai data kepatuhan dari para pelaksana terhadap peraturan dan regulasi pemerintah yang telah ditetapkan. Implementer harus mengetahui apakah orang yang terlibat di dalam pelaksanaan kebijakan tersebut patuh terhadap hukum; (c) wewenang; pada umumnya kewenangan harus bersifat formal agar perintah dapat dilaksanakan. Ketika wewenang nihil, maka kekuatan para implementor di mata publik tidak terlegitimasi, sehingga dapat menggagalkan proses implementasi kebijakan; (d) fasilitas; fasilitas fisik juga merupakan faktor penting dalam implementasi kebijakan. Implementor mungkin memiliki staf yang mencukupi, mengerti apa yang harus dilakukan dan memiliki wewenang untuk melaksanakan tugasnya, tetapi tanpa adanya fasilitas pendukung (sarana dan prasarana) maka implementasi kebijakan tersebut tidak akan berhasil.

3. Disposisi; ariabel ketiga yang mempengaruhi keberhasilan implementasi kebijakan adalah disposisi. Indikator disposisi terdiri dari beberapa elemen, yaitu: (a) pengangkatan birokrat; disposisi atau sikap pelaksana akan menimbulkan hambatan-hambatan yang nyata terhadap implementasi kebijakan. Karena itu, pemilihan dan pengangkatan personil pelaksana kebijakan haruslah orangorang yang memiliki dedikasi pada kebijakan yang telah ditetapkan; (b) insentif; Edward menyatakan bahwa salah satu teknik yang disarankan untuk mengatasi masalah kecenderungan para pelaksana adalah dengan memanipulasi insentif. Dengan cara menambah keuntungan atau biaya tertentu mungkin akan menjadi faktor pendorong yang membuat para pelaksana kebijakan melaksanakan perintah dengan baik. Hal ini dilakukan sebagai upaya memenuhi kepentingan pribadi (self interest) atau organisasi.

4. Struktur birokrasi; walaupun sumber daya untuk melaksanakan suatu kebijakan tersedia, atau para pelaksana kebijakan mengetahui apa yang seharusnya dilakukan, 
dan mempunyai keinginan untuk melaksanakan suatu kebijakan, kemungkinan kebijakan tersebut tidak dapat dilaksanakan atau direalisasikan karena terdapatnya kelemahan dalam struktur birokrasi. Ketika struktur birokrasi tidak kondusif pada kebijakan yang tersedia, maka hal ini akan menyebabkan sumber daya yang ada menjadi tidak efektif dan menghambat jalannya kebijakan. Dua karakteristik yang dapat mendongkrak kinerja struktur birokrasi/organisasi kearah yang lebih baik yaitu: (a) tersedianya Standar Operating Prosedures (SOP); adalah suatu kegiatan rutin yang memungkinkan para pegawai (pelaksana kebijakan/administrator/ birokrat) untuk melaksanakan kegiatan-kegiatannya setiap hari sesuai dengan standar yang ditetapkan atau standar minimum yang dibutuhkan; (b) tersusunnya Fragmentasi; yang merupakan upaya penyebaran tanggung jawab kegiatan-kegiatan atau aktivitasaktivitas pegawai di antara beberapa unit kerja.

Lebih lanjut, untuk memperkaya analisis yang berkaitan dengan upaya yang dilakukan oleh petugas imigrasi terhadap keberadaan dan kegiatan WNA ketika bekerja secara nonprosedural di Indonesia maka digunakan analisis SWOT yang merupakan singkatan dari Strength, Weakness, Opportunity, dan Threats.

Menurut Ricard L. Daft dalam (Tanujaya, 2010), analisis SWOT yakni mencakup upayaupaya untuk mengenali kekuatan, kelemahan, peluang dan ancaman yang menentukan kinerja perusahaan. Informasi eksternal yang mengenai peluang dan ancaman dapat diperoleh dari banyak sumber, termasuk pelanggan, dan dokumen pemerintah, pemasok, kalangan perbankan, rekan perusahaan lain. Sedangkan menurut (Rangkuti, 2004), analisis SWOT adalah identifikasi berbagai faktor secara sistematis untuk merumuskan strategi perusahaan. Analisis ini didasarkan pada logika yang dapat memaksimalkan kekuatan (strength) dan peluang (opportunity), namun secara bersamaan dapat meminimalkan kelemahan (weakness) dan ancaman (threats). Proses pengambilan keputusan strategi selalu berkaitan dengan pengembangan misi, tujuan, strategi dan kebijakan perusahaan.(Rangkuti, 2004) Dengan demikian, perencanaan strategi harus menganalisa faktor-faktor strategi perusahaan (kekuatan, kelemahan, peluang dan ancaman) pada saat ini. Analisis SWOT membandingkan antara faktor eksternal, yaitu: peluang (opportunity) dan ancaman (threats) dengan faktor internal, yaitu: kekuatan (strenght) dan kelemahan (weakness).

\section{HASIL DAN PEMBAHASAN}

Pemahaman mengenai orang asing bekerja secara nonprosedural dapat dimaknai sebagai seseorang yang melakukan kegiatan namun tidak memiliki dokumen resmi yang ditetapkan oleh peraturan perundang-undangan. Pada prinsipnya untuk bekerja secara legal di Indonesia, orang asing harus memiliki Izin Mempekerjakan Tenaga Asing (selanjutnya disebut IMTA) dan Rencana Penggunaan Tenaga Kerja Asing (RPTKA) dari perusahaan tempat orang asing bekerja (Kementerian Ketenagakerjaan Republik Indonesia, Pasal 4 ayat (4) poin a Peraturan Menteri Ketenagakerjaan Republik Indonesia Nomor 10 Tahun 2018 Tentang Tata Cara Penggunaan Tenaga Kerja Asing (Indonesia, 2018). yang kemudian berdasarkan pasal 5 Peraturan sebelumnya, pihak imigrasi baru dapat mengeluarkan Visa Tinggal Terbatas (selanjutnya disebut VITAS) dan KITAS) bagi orang asing yang akan bekerja di Indonesia jika sudah memiliki IMTA dan RPTKA.

\section{A. Penyebab WNA Bekerja Secara Nonprosedural di Indonesia}

Dari hipotesis yang telah dijabarkan sebelumnya maka dapat dianalisis dengan pendekatan multidimensional untuk mendapatkan gambaran yang utuh dan komprehensif. Akan tetapi perspektif yang digunakan dalam menganalisis hanya difokuskan pada pendekatan hukum dan keimigrasian. Pendekatan hukum yang dimaksud menggunakan perspektif Teori "Model" Sistem Hukum Lawrence M. Friedman, sedangkan pendekatan Keimigrasian menggunakan perspektif Teori Implementasi Kebijakan George Edward III. Lebih lanjut, untuk memperkaya analisis, juga menggunakan pendekatan SWOT yang secara khusus untuk menganalisis upaya pengawasan dan penindakan terhadap orang asing baik oleh Direktorat Jenderal Imigrasi maupun Timpora.

Hipotesis pertama menyatakan bahwa keberadaan celah dalam regulasi/kebijakan keimigrasian dan ketenagakerjaan berpeluang dimanfaatkan oleh WNA untuk bekerja secara nonprosedural di Indonesia. Pernyataan ini didukung oleh data temuan lapangan secara 
kualitatif yang menyatakan bahwa WNA memanfaatkan kebijakan BVK yang disampaikan oleh Petugas Imigrasi, Pengawas Ketenagakerjaan, Perwakilan Ombudsman Republik Indonesia, dan Akademisi.

Merujuk pada analisis Model Sistem Hukum Lawrence M. Friedman, salah satu diantaranya berbicara mengenai persoalan substansi hukum (legal substance). Substansi hukum sendiri berkaitan dengan sistem substansial yang menentukan bisa atau tidaknya hukum itu dilaksanakan, produk yang dihasilkan oleh orang yang berada dalam sistem hukum yang mencakup keputusan yang mereka keluarkan atau aturan baru yang mereka susun. Dalam kalimat yang sederhana, adalah berbicara tentang produk hukum berikut kebijakan yang mengilhaminya, yakni apakah substansi hukum dalam suatu regulasi atau dasar dari suatu kebijakan yang diambil sudah baik. Berikut akan dijelaskan keterkaitan antara aspek substansi hukum dengan keberadaan celah dalam regulasi/kebijakan keimigrasian dan ketenagakerjaan yang berpeluang dimanfaatkan oleh WNA untuk bekerja secara nonprosedural di Indonesia.

Pertama, berkaitan dengan celah dalam regulasi/peraturan baik Keimigrasian maupun Ketenagakerjaan. Celah hukum yang dimaksud di sini tidak terbatas pada celah hukum yang disebabkan karena penafsiran "frasa" dalam pasal semata melainkan lebih kepada hal-hal yang belum diatur dalam regulasi/peraturan yang ada, serta semangat ataupun filosofi yang melatarbelakangi pembentukan regulasi/peraturan terkait. Dari sisi Keimigrasian, setidaknya terdapat 3 celah hukum dalam regulasi/peraturan Keimigrasian yang berhubungan dengan penyalahgunaan izin tinggal sebagai berikut:

\section{Penyalahgunaan Visa Kunjungan}

Dalam praktiknya, modus operandi yang sering dilakukan oleh WNA yakni masuk ke Indonesia dengan menggunakan Visa Kunjungan akan tetapi kemudian disalahgunakan untuk bekerja di Indonesia. Dipilihnya Visa Kunjungan dikarenakan biaya penerbitannya yang lebih murah dan proses pembuatannya yang lebih singkat daripada VITAS untuk Bekerja (Indeks 311-312). Visa Kunjungan berlaku selama 60 hari dan dapat diperpanjang sebanyak maksimal 5 kali masing masing 30 hari dengan total 210 hari. Seperti yang sering terjadi di Batam, Kepulauan Riau dan
Timor Leste. Modus ini merupakan celah karena belum diatur dalam UndangUndang Keimigrasian maupun peraturan teknis di bawahnya.

2. Penyalahgunaan Visa on Arrival (VoA)

Modus yang kedua adalah penyalahgunaan Visa on Arrival, biasanya WNA dari negara dengan status VoA memanfaatkan celah hukum ini untuk masuk ke Indonesia dan melakukan aktivitas diluar peruntukan visanya, termasuk bekerja. Alasan pemilihan VoA dikarenakan biaya yang lebih murah dan prosesnya yang lebih sederhana dibandingkan Visa Kunjungan. VoA ini berlaku selama 30 hari dan dapat diperpanjang 1 (satu) kali yang berlaku selama 30 hari dengan total kumulatif 60 hari. Modus ini merupakan celah karena belum diatur dalam Undang-Undang Keimigrasian maupun peraturan teknis di bawahnya.

3. Penyalahgunaan BVK

Modus yang ketiga adalah penyalahgunaan BVK, dalam beberapa kasus WNA masuk ke Indonesia dengan fasilitas BVK sambil mengurus KITAS untuk bekerja. Sesuai PERPRES No. 21/2016 tentang BVK, peruntukan BVK bukanlah untuk bekerja. Sembari menunggu proses KITAS, WNA biasanya sudah bekerja di Indonesia padahal jelas ini merupakan sebuah bentuk pelanggaran. BVK sendiri diberikan kepada WNA asal negara dengan status BVK selama maksimal 30 hari saja. Pada sisi yang lain, tidak menutup kemungkinan BVK disalahgunakan oleh WNA yang bekerja secara komersial di Indonesia dalam pekerjaan yang membutuhkan waktu singkat seperti konsultan, pebisnis, periset, pengacara, jurnalis, dokter spesialis dan tenaga ahli lainnya. Meskipun demikian, temuan di lapangan bersifat sporadis dan kasuistik.

Kedua, Kerjasama Penanaman Modal (Investasi) di Indonesia antara Indonesia dengan Negara lain yang pada salah satu klausulnya mensyaratkan "kewajiban" penggunaan tenaga kerja dari negara investor. Kerjasama ini seharusnya menggunakan TKA ahli yang prosedural akan tetapi tidak dipungkiri dengan adanya celah dalam kebijakan BVK dan juga celah dalam regulasi mengenai Visa Kunjungan dan VoA, TKA dapat bekerja secara nonprosedural. Meskipun demikian, tim penelitian menemui kesulitan untuk 
mendapatkan salinan dari MoU kerjasama investasi Government to Government dimaksud.

Ketiga, adanya kontradiksi dalam implementasi prinsip dan asas Keimigrasian dengan peraturan perundang-undangan lainnya, dimana Keimigrasian menganut prinsip selective policy dan asas resiprokal. Prinsip Selective Policy adalah suatu kebijakan berdasarkan prinsip selektif. Berdasarkan prinsip ini, hanya orang-orang asing yang dapat memberikan manfaat bagi kesejahteraan rakyat, bangsa dan negara Republik Indonesia, yang tidak membahayakan keamanan dan ketertiban serta tidak bermusuhan baik terhadap rakyat maupun Negara Kesatuan Republik Indonesia yang berdasarkan kepada Pancasila dan Undang-Undang Dasar 1945, yang diizinkan masuk atau keluar wilayah Indonesia. Untuk itu perlu ada pengaturan dan batasan berupa perizinan yang diberikan kepada orang asing apabila hendak tinggal di Indonesia melalui aturan hukum yang telah ditetapkan (sitasi). Sementara asas resiprokal (timbal balik) merujuk pada pemberian fasilitas yang sama terhadap WNI yang berkunjung ke negaranegara yang mendapatkan status bebas visa. Akan tetapi, dalam implementasinya adanya peraturan lain yang memberikan ruang seluasluasnya bagi 169 negara (negara dengan status bebas visa) untuk masuk ke Indonesia sehingga menimbulkan dampak terkait penyalahgunaan dokumen keimigrasian. Sementara sampai saat ini Indonesia hanya menerima status bebas visa kunjungan dari 15 negara saja sehingga memperlihatkan ketimpangan yang serius.

Keempat, dasar hukum pembentukan Timpora masih lemah dan bersifat sektoral. Hal ini disebabkan dasar hukum pembentukan Timpora yang sebatas pada Permenkumham (Permenkumham Nomor 50 Tahun 2016) dimana ruang lingkup peraturan ini hanya mencakup internal Kementerian Hukum dan HAM saja. Sementara Ditjen Imigrasi memiliki peran sebagai leading sector dalam hal pengawasan dan penindakan terhadap orang asing, sehingga aturan yang demikian membatasi ruang gerak Ditjen Imigrasi. Dengan demikian, maka perlu dilakukan penguatan terhadap keberadaan Timpora dengan penerbitan dasar hukum yang lebih tinggi sehingga dapat mencakup tugas dan fungsi pengawasan dan penindakan terhadap orang asing pada stakeholder terkait lainnya.

Hipotesis kedua menyatakan bahwa minimnya Sumber Daya Manusia pada UPT
Imigrasi dan Ketenagakerjaan khususnya dalam bidang pengawasan dan penindakan menjadi penyebab WNA bekerja secara nonprosedural di Indonesia. Pernyataan ini didukung oleh data temuan lapangan kualitatif yang menyatakan bahwa jumlah petugas pengawas (dalam hal ini PPNS) masih belum memadai jika dibandingkan dengan luas wilayah yang harus diawasi, walaupun dalam hal tertentu petugas pengawas juga dibantu oleh unsur-unsur yang lain. Selain persoalan kuantitas petugas, permasalahan lainnya terletak pada kompetensi petugas itu sendiri. Menurut Jajaran Imigrasi dan Ketenagakerjaan persoalan kompetensi petugas salah satunya berhubungan erat dengan pemberian pendidikan dan pelatihan khusus yang mereka sadari masih belum terlaksana. Pendidikan dan pelatihan khusus dimaksud disini adalah yang berhubungan dengan pengawasan dan penindakan baik keimigrasian maupun ketenagakerjaan, seperti diklat PPNS.

Sampai saat ini berdasarkan data dari Ditjen Imigrasi Tahun 2018 diketahui jumlah petugas yang melaksanakan fungsi pengawasan dan penindakan Keimigrasian sebanyak 295 orang yang tersebar pada 125 Kanim (kantor imigrasi) di 33 provinsi. Dengan melihat data tersebut, dapat diasumsikan pada setiap Kanim terdapat 2 orang petugas di bidang pengawasan dan penindakan Keimigrasian.

Dari temuan di lapangan dapat diketahui bahwa jumlah pengawas ketenagakerjaan masih belum memadai sehingga menjadi kendala saat melakukan pengawasan dan penindakan terhadap WNA yang bekerja di Indonesia. Berdasarkan data dari International Labour Organization (ILO) dan Kemenaker, jumlah pengawas ketenagakerjaan di Indonesia tahun 2016 sebanyak 1.923 orang yang tersebar di 34 provinsi sedangkan jumlah perusahaan yang harus diawasi sebanyak 21.591 .508 perusahaan. Dengan demikian rasio pengawas terhadap perusahaan di Indonesia adalah 1:11.228.

Merujuk pada poin kedua Teori Sistem Hukum Lawrence M. Friedman yaitu struktur hukum yang berkaitan dengan sistem struktural yang menentukan bisa atau tidaknya hukum itu dilaksanakan dengan baik mensyaratkan penegakan oleh aparat penegak hukum yang kredibel, kompeten dan independen. Berbicara mengenai penegakan hukum tidak dapat dipisahkan dengan faktor SDM. Hal demikian dapat dipahami bahwa hukum dapat berfungsi dengan baik salah satunya jika didukung oleh SDM yang kredibel, kompeten dan independen. 
Sebelum berbicara mengenai SDM yang kredibel, kompeten dan independen, aspek ketersediaan SDM menjadi poin kunci pertama. Berkaitan dengan hal tersebut, dalam konteks pengawasan dan penindakan terhadap WNA yang bekerja secara nonprosedural terdapat satu aspek yang berpengaruh secara signifikan yaitu kurangnya SDM baik dari sisi jumlah maupun kompetensi. Selain persoalan jumlah dan kompetensi SDM ditemukan juga persoalan integritas/moralitas dari aparat pengawas dan atasan. Seperti terjadinya intervensi "atasan" ketika inspeksi dadakan dilaksanakan serta adanya oknum pengawas yang menyalahgunakan wewenang di lapangan.

Hipotesis ketiga menyatakan bahwa minimnya Sarana dan Prasarana pada UPT Imigrasi dan Ketenagakerjaan khususnya dalam bidang pengawasan dan penindakan menjadi penyebab WNA bekerja secara nonprosedural di Indonesia. Pernyataan ini didukung oleh data hasil wawancara dengan Jajaran Imigrasi dan Ketenagakerjaan yang menyatakan bahwa sarana dan prasarana penunjang dalam bidang pengawasan dan penindakan terhadap WNA atau TKA di Indonesia belum memadai. Sarana dan prasarana dimaksud berupa kendaraan operasional, sistem teknologi informasi dan dukungan kecukupan anggaran.

Sarana yang dimaksud adalah kendaraan operasional dalam menjalankan tugas dan fungsi pengawasaan. dari hasil temuan lapangan di Provinsi Kepulauan Riau dimana Jajaran Imigrasi Batam hanya memiliki 2 buah kapal operasional untuk pengawasan dan penindakan. Selain permasalahan jumlah, permasalahan lain juga dapat dilihat dari spesifikasi kapal yang belum memadai dan keterbatasan anggaran operasional misalnya untuk membeli bahan bakar dan juga maintenance kapal. Hal yang sama juga dapat terlihat pada ketersediaan perlengkapan penunjang seperti senjata pengamanan (senjata api, borgol dll) juga masih minim sehingga dalam penanganan WNA yang bekerja secara nonprosedural di Indonesia dirasakan masih belum memadai. Masalah yang sama juga dapat dilihat pada kendaraan operasional jenis lainnya. Hambatan tersebut diatas juga dialami oleh petugas pengawas ketenagakerjaan.

Terkait dengan fungsi pengawasan dan penindakan terhadap WNA di Indonesia diharapkan agar Ditjen Imigrasi mengembangkan suatu sistem teknologi informasi terintegrasi yang berhubungan dengan pengawasan perlintasan WNA pada jalur domestik untuk mengetahui posisi/keberadaan mereka selama berada di Indonesia. Khusus untuk WNA yang bekerja di Indonesia agar Jajaran Imigrasi dan Ketenagakerjaan membangun sistem terintegrasi serupa yang berfokus pada pertukaran data dan informasi terkait dengan WNA dan TKA dalam rangka mendukung fungsi pengawasan dan penindakan.

Pada sisi yang lain, berkaitan dengan dukungan anggaran terhadap fungsi pengawasan dan penindakan baik Keimigrasian maupun Ketenagakerjaan dirasakan masih belum memadai. Dari hasil wawancara dengan Jajaran Imigrasi misalnya, diketahui bahwa terdapat pengurangan anggaran tahun 2018 untuk pengawasan dan penindakan keimigrasian dikarenakan pengalihan anggaran untuk pembiayaan kegiatan yang lain.

Paralel dengan peran penting SDM dalam upaya membangun struktur hukum yang baik sebagaimana telah dijelaskan sebelumnya, ketersediaan Sarana dan Prasarana juga menjadi faktor yang sama pentingnya. Dukungan SDM dan sarana-prasarana yang memadai berkontribusi bagi terciptanya struktur hukum yang baik pula.

Teori Sistem Hukum Lawrence M. Friedman juga mengidentifikasi keberadaan budaya hukum sebagai salah satu faktor penentu keberhasilan penegakan hukum. Adapun budaya hukum berkaitan erat dengan sikap manusia terhadap hukum dan sistem hukum atau kepercayaan, nilai, pemikiran, serta harapannya atau dalam istilah lain kesadaran hukum masyarakat. Meskipun tidak disebutkan dalam hipotesis penelitian, Tim peneliti menganggap penting untuk menjelaskan aspek ini dalam analisis. Hal ini mengingat korelasi yang kuat dan utuh antara substansi, struktur dan budaya hukum. Selain itu, senada dengan hal sebelumnya, fenomena mengenai budaya hukum juga tergambar dalam data kualitatif yang berhasil dikumpulkan, seperti sikap permisif dan acuh masyarakat terhadap keberadaan WNA dilingkungan mereka; aspek kepatuhan hukum di lingkup masyarakat yang masih cukup lemah, termasuk pula pada aspek kepatuhan hukum korporasi terkait penggunaan TKA; sikap sebagian masyarakat yang melindungi WNA pelanggar hukum/aturan apabila dipandang menguntungkan bagi mereka; ego sektoral antar instansi pemangku kepentingan yang menjadi salah satu sebab kurang optimalnya koordinasi dalam hal 
pengawasan dan penindakan terhadap WNA dan lain sebagainya.

Dari uraian analisis diatas, diketahui bahwa temuan hasil lapangan mendukung dan menguatkan hipotesis 1 - 3. Pernyataan ini bersesuaian dengan hipotesis pertama, kedua dan ketiga yang didukung oleh hasil temuan di lapangan. Merujuk pada Teori Sistem Hukum Lawrence M. Friedman yang menyatakan bahwa berhasil atau tidaknya penegakan hukum dipengaruhi oleh 3 aspek yaitu substansi hukum, struktur hukum dan budaya hukum. Secara sederhana penegakan hukum baru dapat dikatakan berhasil apabila didukung oleh substansi hukum, struktur hukum dan budaya hukum yang baik. Substansi hukum sendiri berkaitan dengan sistem substansial yang menentukan bisa atau tidaknya hukum itu dilaksanakan, produk yang dihasilkan oleh orang yang berada dalam sistem hukum yang mencakup keputusan yang mereka keluarkan atau aturan baru yang mereka susun. Sementara struktur hukum berkaitan dengan sistem struktural yang menentukan bisa atau tidaknya hukum itu dilaksanakan dengan baik yang mensyaratkan penegakan oleh aparat penegak hukum yang kredibel, kompeten dan independen. Adapun budaya hukum berkaitan erat dengan sikap manusia terhadap hukum dan sistem hukum atau kepercayaan, nilai, pemikiran, serta harapannya atau dalam istilah lain kesadaran hukum masyarakat. Ketiga aspek tersebut saling terhubung layaknya analogi pekerjaan mekanik, struktur diibaratkan sebagai mesin, substansi adalah apa yang dikerjakan dan dihasilkan oleh mesin sedangkan budaya hukum adalah apa saja atau siapa saja yang memutuskan untuk menghidupkan atau mematikan mesin serta memutuskan bagaimana mesin itu digunakan.

Dalam kaitannya dengan hipotesis pertama, kedua, dan ketiga, didapatkan hubungan bahwa keberadaan celah dalam regulasi/kebijakan keimigrasian yang merupakan bagian dari aspek substansi hukum dan minimnya Sumber Daya Manusia serta sarana-prasarana pada UPT Imigrasi khususnya dalam bidang pengawasan dan penindakan yang merupakan bagian dari aspek struktur hukum menjadi kontributor utama bagi belum optimalnya upaya Petugas Imigrasi dalam melakukan pengawasan dan penindakan terhadap keberadaan dan kegiatan WNA di Indonesia.

\section{B. Upaya-upaya yang dilakukan Petugas Imigrasi terhadap keberadaan dan kegiatan Warga Negara Asing di Indonesia} Pengawasan terhadap keberadaan dan kegiatan orang asing di Indonesia sejatinya bukan hanya merupakan tugas dan fungsi Ditjen Imigrasi saja melainkan juga merupakan tugas dan fungsi pemangku kepentingan terkait lainnya. Dalam implementasinya, paradigma mengenai orang asing selalu tertuju dan dikaitkan dengan Keimigrasian. Padahal, ketika kita berbicara mengenai orang asing banyak aspek dan institusi lain yang terlibat didalamnya.

Dalam konteks keimigrasian tugas dan fungsi dari jajaran Imigrasi terbatas pada entry dan exit point berupa pemeriksaan dan penerbitan dokumen keimigrasian atau hanya melingkupi titik hulu dan hilir dari pengawasan terhadap orang asing. Peran pengawasan dan penindakan terhadap orang asing pada zona antara yakni ketika orang asing tersebut sudah keluar dari TPI otomatis juga menjadi domain pengawasan dan penindakan stakeholder lainnya. Dalam pendekatan yang holistik, pengawasan dan penindakan terhadap orang asing yang efektif membutuhkan kerjasama dan sinergi dari stakeholder terkait.

Hal inilah yang melatarbelakangi pembentukan Timpora dengan diterbitkannya Permenkumham Nomor 50 Tahun 2016. Timpora adalah wadah dengan fungsi koordinatif yang terdiri atas instansi atau lembaga pemerintah yang mempunyai tugas dan fungsi untuk mewujudkan pengawasan yang terkoordinasi dan menyeluruh terhadap keberadaan dan kegiatan orang asing di wilayah Indonesia. Dalam Permenkumham Nomor 50/2016 tentang Timpora, disebutkan bahwa Timpora memiliki fungsi koordinasi dan pertukaran data dan informasi serta pengumpulan informasi dan data keberadaan orang asing secara berjenjang dari tingkat desa, kelurahan, kecamatan, kabupaten, kota sampai dengan provinsi.

Dalam perjalanannya, Timpora mengalami kendala dalam melaksanakan tugas dan fungsinya untuk melakukan pengawasan terhadap orang asing di Indonesia, salah satunya disebabkan oleh dasar hukum pembentukan Timpora yang lemah, yakni hanya terbatas setingkat Peraturan Menteri (Permen) yang hanya mengikat kedalam.

Selanjutnya berkaitan dengan upaya yang dilakukan oleh Petugas imigrasi terhadap keberadaan dan kegiatan WNA di Indonesia, 
maka implementasi sering dianggap hanya merupakan pelaksanaan dari apa yang telah diputuskan oleh atasan atau para pengambil keputusan. Seolah-olah tahapan ini kurang berpengaruh, namun dalam kenyataannya, tahapan implementasi menjadi begitu penting karena suatu kebijakan tidak akan berarti apaapa jika tidak dapat dilaksanakan dengan baik dan benar. Dengan kata lain implementasi merupakan tahap dimana suatu kebijakan dilaksanakan secara maksimal dan dapat mencapai tujuan kebijakan itu sendiri. Implementasi dapat dimulai dari kondisi abstrak dan sebuah pertanyaan tentang apakah syarat agar implementasi kebijakan dapat berhasil. Berdasarkan Teori Implementasi Kebijakan oleh George Edward III ada empat variabel dalam kebijakan publik yaitu: Komunikasi (communications), Sumber Daya (resources), Disposisi (sikap atau attitudes) dan Struktur Birokrasi (bureucratic structure). Ke empat factor tersebut harus dilaksanakan secara simultan karena antara satu dengan yang lainnya memiliki hubungan yang erat. Implementasi kebijakan adalah suatu proses dinamik yang mana-meliputi interaksi banyak faktor sehingga dapat diketahui pengaruhnya terhadap implementasinya.

Komunikasi dalam implementasi kebijakan mencakup beberapa dimensi penting, yaitu: tranformasi informasi (transimisi), kejelasan informasi (clarity) dan konsistensi informasi (consistency). Dimensi tranformasi menghendaki agar informasi tidak hanya disampaikan kepada pelaksana kebijakan tetapi juga kepada kelompok sasaran dan pihak yang terkait. Dimensi kejelasan menghendaki agar informasi yang jelas dan mudah dipahami, selain itu untuk menghindari kesalahan interpretasi dari pelaksana kebijakan, kelompok sasaran maupun pihak yang terkait dalam implementasi kebijakan. Sedangkan dimensi konsistensi menghendaki agar informasi yang disampaikan harus konsisten sehingga tidak menimbulkan kebingungan pelaksana kebijakan, kelompok sasaran maupun pihak terkait. Terjadinya pertentangan antara pelaksana kebijakan dengan perintah yang dikeluarkan oleh pembuat kebijakan mengakibatkan distorsi dan hambatan yang langsung dalam komunikasi kebijakan, sehingga dalam pelaksanaan pengawasan dan penindakan keimigrasian di lapangan mengalami distorsi. Distorsi komunikasi dapat terjadi karena panjangnya rantai informasi yang dapat mengakibatkan bias informasi dan masalah penangkapan informasi juga diakibatkan oleh persepsi dan ketidakmampuan para pelaksana dalam memahami persyaratanpersyaratan suatu kebijakan. Dengan semakin banyak lapisan atau aktor pelaksana yang terlibat dalam implementasi kebijakan, maka semakin besar kemungkinan hambatan dan distorsi yang dihadapi.

Sumber daya memiliki peranan penting, bagaimanapun akuratnya penyampaian ketentuan-ketentuan atau aturan-aturan tersebut, jika para pelaksana kebijakan yang bertanggung jawab untuk melaksanakan kebijakan kurang mempunyai sumber-sumber daya untuk melaksanakan kebijakan secara efektif, maka implementasi kebijakan tersebut tidak akan efektif. Sumber daya di sini mencakup beberapa dimensi yaitu: sumber daya manusia (staff), anggaran (budgetary), fasilitas (facility), serta informasi dan kewenangan (information and authority). Dimensi SDM menghendaki adanya kualitas SDM berkaitan dengan keterampilan, dedikasi, profesionalitas, dan kompetensi di bidang pengawasan dan penindakan keimigrasian. Sedangkan kuatitas berkaitan dengan jumlah SDM, apakah sudah cukup untuk melingkupi tugas dan fungsi pengawasan dan penindakan keimigrasian. Implementasi kebijakan tidak akan berhasil tanpa adanya dukungan dari sumber daya manusia yang cukup kualitas dan kuantitasnya. Dimensi anggaran berkaitan dengan kecukupan modal atau investasi atas suatu program atau kebijakan untuk menjamin terlaksananya kebijakan, sebab tanpa dukungan anggaran yang memadai, kebijakan tidak akan berjalan dengan efektif dalam mencapai tujuan dan sasaran pengawasan dan penindakan keimigrasian. Dimensi fasilitas menghendaki adanya pengadaan fasilitas yang layak, seperti gedung, kendaraan operasional dan sistem teknologi informasi yang menunjang dalam keberhasilan implementasi suatu program atau kebijakan. Sementara dimensi informasi dan kewenangan menghendaki adanya informasi yang relevan dan cukup terkait bagaimana mengimplementasikan suatu kebijakan dan wewenang berperan untuk meyakinkan dan menjamin bahwa kebijakan yang dilaksanakan sesuai dengan yang dikehendaki. Kegagalan yang sering terjadi dalam implementasi kebijakan, salah-satunya disebabkan oleh staf atau pegawai yang tidak cukup memadai, mencukupi, ataupun tidak kompeten dalam bidangnya. Penambahan jumlah staf saja tidak cukup menyelesaikan 
persoalan implementasi kebijakan, tetapi diperlukan sebuah kecukupan staf dengan keahlian dan kemampuan yang diperlukan (kompeten dan kapabel) dalam mengimplementasikan kebijakan serta anggaran yang memadai pula. Begitu pun dengan fasilitas fisik; organisasi mungkin sudah mempunyai staf yang mencukupi, kapabel dan kompeten, tetapi tanpa adanya fasilitas pendukung (sarana dan prasarana) maka implementasi kebijakan tersebut tidak akan berhasil.

Disposisi dari pelaksana kebijakan akan sangat berpengaruh dalam implementasi kebijakan. Hal ini dapat terlihat dari kecenderungan perilaku atau karakteristik pelaksana kebijakan untuk mewujudkan implementasi kebijakan yang sesuai dengan tujuan atau sasaran. Karakter yang harus dimiliki oleh pelaksana kebijakan, misalnya kejujuran dan komitmen yang tinggi. Kejujuran mengarahkan pelaksana kebijakan pada program yang telah digariskan, sedangkan komitmen yang tinggi dari pelaksana kebijakan akan membuat antusias dalam melaksanakan tugas dan fungsi pengawasan dan penindakan keimigrasian. Disposisi atau sikap pelaksana dalam melakukan pengangkatan dan pemilihan personel pelaksana kebijakan haruslah dipilih orang-orang yang memiliki dedikasi pada kebijakan yang telah ditetapkan dan lebih khusus lagi pada kepentingan warga masyarakat. Pemberian insentif merupakan salah satu teknik yang disarankan untuk mengatasi masalah sikap para pelaksana kebijakan dengan memanipulasi insentif. Dengan cara menambah keuntungan atau biaya tertentu mungkin akan menjadi faktor pendorong yang membuat para pelaksana menjalankan perintah dengan baik. Hal ini dilakukan sebagai upaya memenuhi kepentingan pribadi atau organisasi.

Aspek struktur organisasi di sini melingkupi dua dimensi, yaitu: mekanisme dan struktur birokrasi itu sendiri. Dimensi mekanisme meghendaki adanya standard operation procedure (SOP) yang menjadi pedoman bagi setiap para pelaksana dalam bertindak agar dalam pelaksanaan kebijakan tidak melenceng dari tujuan dan sasarannya. Dimensi struktur birokrasi yang terlalu panjang dan terfragmentasi menyebabkan prosedur birokrasi yang rumit dan kompleks yang selanjutnya akan menyebabkan aktivitas organisasi menjadi tidak fleksibel dan cenderung melemahkan pengawasan dan penindakan keimigrasian. Implementasi kebijakan yang bersifat kompleks menuntut adanya kerjasama banyak pihak. Ketika strukur birokrasi tidak kondusif terhadap implementasi suatu kebijakan, maka hal ini akan menyebabkan ketidakefektifan dan menghambat jalanya pelaksanaan kebijakan.

Dengan menggunakan SOP, para pelaksana dapat mengoptimalkan waktu yang tersedia dan dapat berfungsi untuk menyeragamkan tindakan-tindakan pejabat dalam organisasi yang kompleks dan tersebar luas, sehingga dapat menimbulkan fleksibilitas yang besar dan kesamaan yang besar dalam penerapan peraturan. Pada umumnya, semakin besar koordinasi yang diperlukan untuk melaksanakan kebijakan, semakin berkurang kemungkinan keberhasilan program atau kebijakan. Fragmentasi mengakibatkan pandanganpandangan yang sempit dari banyak lembaga birokrasi. Hal tersebut terjadi karena tidak ada otoritas yang kuat dalam implementasi kebijakan yang disebabkan terpecahnya fungsifungsi tertentu ke dalam lembaga atau badan yang berbeda-beda. Di samping itu, masingmasing badan mempunyai yurisdiksi yang terbatas atas suatu bidang, maka tugas-tugas yang penting mungkin akan terlantarkan dalam berbagai agenda birokrasi yang menumpuk dan pandangan yang sempit dari badan yang mungkin juga akan menghambat perubahan.

Pengaruh dimensi komunikasi, sumber daya, disposisi dan struktur birokrasi mempunyai pengaruh signifikan terhadap kinerja petugas imigrasi baik secara parsial (terpisah sendiri-sendiri) maupuan secara simultan. Namun demikian, ditemukan hambatan komunikasi dan pemahaman tugas serta tanggung jawab yang kurang dari petugas pengawas dan penindakan keimigrasian serta jumlah SDM dan sarana prasarana yang belum memadai bila ditinjau dari kualitas dan kuantitasnya.

Pada akhirnya dapat dirumuskan bahwa dalam rangka melakukan pengawasan dan penindakan, beberapa Kantor Imigrasi sesuai lokus penelitian telah melakukan beberapa upaya diantaranya: (1) sosialisasi dan edukasi kepada masyarakat sekitar tentang keberadaan dan aktivitas WNA di Indonesia; (2) pelaporan informasi melalui Aplikasi Pelaporan Orang Asing (APOA) jika masyarakat mencurigai kegiatan ataupun keberadaan WNA yang berpotensi melakukan pelanggaran keimigrasian; (3) pelibatan masyarakat sebagai 
informan karena terdapat peluang masyarakat melindungi WNA akibat faktor ekonomi dan sosial; (4) melakukan pengintaian dan/atau penyamaran ketika memperoleh laporan dari masyarakat dengan tujuan untuk mengumpulkan bukti agar dapat diproses dan dilakukan penindakan; (5) ketika menerima informasi yang akurat dari Timpora atau informan, maka petugas imigrasi melakukan tindakan yang meliputi pengumpulan data kembali, menangkap pelaku, membuat putusan, kemudian memberikan tindakan administratif keimigrasian atau pro justitia; (6) pembentukan Timpora dengan kewenangan berbeda-beda pada setiap instansi sampai tingkat kecamatan yang bertugas untuk mengawasi dan melakukan penindakan atas keberadaan orang asing (WNA) termasuk pekerja nonprosedural.

\section{KESIMPULAN}

Berdasarkan pembahasan sebelumnya maka dapat disimpulkan bahwa penyebab orang asing bekerja secara nonprosedural di Indonesia dipengaruhi oleh: pertama, pemanfaatan "celah" kebijakan atau regulasi terkait keimigrasian yang meliputi penyalahgunaan Visa Kunjungan, penyalahgunaan VoA, penyalahgunaan BVK, dan dasar hukum pembentukan Tim Pengawasan Orang Asing masih lemah dan bersifat sektoral. Kedua, jumlah dan kompetensi petugas dan dukungan saranaprasarana termasuk anggaran di bidang pengawasan dan penindakan Keimigrasian maupun Ketenagakerjaan yang belum memadai, menjadi kontributor lainnya bagi keberadaan orang asing yang bekerja secara nonprosedural di Indonesia. Ketiga, adanya intervensi dari oknum pihak-pihak tertentu yang berkuasa melegalkan orang asing untuk bekerja secara nonprosedural. Intervensi ini mempengaruhi tindakan petugas di lapangan untuk menegakkan ketentuan yang berlaku. Keempat, sebagian masyarakat masih acuh dan permisif terhadap keberadaan orang asing yang bekerja secara nonprosedural, masyarakat juga sangat permisif dengan tindakan oknum petugas (Imigrasi dan Ketenagakerjaan) yang melegalkan orang asing untuk bekerja secara nonprosedural yang didukung oleh oknum pegawai korporasi sebagai pemberi kerja.

Selanjutnya upaya-upaya yang telah dilakukan oleh Petugas Imigrasi untuk mencegah warga negara asing yang bekerja secara nonprosedural di Indonesia, meliputi pertama, memanfaatkan APOA untuk menerima informasi tentang keberadaan dan kegiatan WNA yang bekerja sama dengan pengelola penginapan (hotel, vila dan tempat kos). Kedua, melakukan sosialisasi dan edukasi serta memanfaatkan masyarakat sebagai informan tentang keberadaan dan kegiatan WNA di Indonesia.dan Ketiga, menguatkan peran Tim Pengawasan Orang Asing dengan cara melakukan koordinasi antar instansi terkait untuk mengetahui keberadaan dan kegiatan serta melakukan tindakan terhadap WNA yang melakukan pelanggaran atau bekerja secara nonprosedural.

Berdasarkan hasil pembahasan dan kesimpulan sebelumnya, maka dapat disarankan kepada Pemerintah untuk:

1. Melakukan perbaikan-perbaikan terhadap aturan-aturan yang dinilai memberikan celah atau peluang bagi orang asing untuk bekerja secara nonprosedural di Indonesia.

2. Mengembangkan sistem teknologi informasi yang berkaitan dengan pengawasan pelintasan orang asing pada jalur domestik.

3. Mengoptimalkan fungsi pengawasan dan penindakan keimigrasian melalui pemenuhan kebutuhan pegawai yang kredibel dan kapabel maupun sarana prasarana yang dibutuhkan pada Tempat Pemeriksaan Imigrasi dan kantor-kantor Imigrasi di Indonesia.

4. Memaksimalkan peran serta masyarakat untuk dapat memberikan informasi perihal keberadaan orang asing yang dicurigai atau melakukan pekerjaan secara non prosedural di wilayahnya

\section{UCAPAN TERIMA KASIH}

Ucapan terima kasih disampaikan kepada pihakpihak yang memberikan bantuan selama pelaksanaan penelitian/penulisan artikel diantaranya kepada Kepala Badan Penelitian dan Pengembangan Hukum dan Hak Asasi Manusia Kementerian Hukum dan Hak Asasi Manusia Republik Indonesia beserta jajarannya yang telah memberikan kesempatan untuk melakukan penelitian, kepada tim peneliti yang terlibat dalam penelitian serta pihak editor maupun mitra bestari yang telah membantu dalam perbaikan atau koreksi terhadap tulisan maupun teknik penulisan dalam artikel ini.

\section{DAFTAR PUSTAKA}

\author{
A.S. Homby. (1984). Oxford Advanced Learner \\ Dictionary Of Current English. Oxford \\ University Press.
}


Agustino, L. (2008). Dasar-Dasar Kebijakan Publik. Alfabeta.

Andreas, D. (2018). BPS: 7 Juta Orang Indonesia Menganggur, Paling Banyak Lulusan SMK. Tirto.Id. https://tirto.id/bps7-juta-orang-indonesia-menganggurpaling-banyak-lulusan-smk-c9c9\%0D

Belarminus, R. (2017). Data Imigrasi: Sepanjang 2017, Warga China Paling Banyak Masuk ke Indonesia. Tribunnews.Com.

http://www.tribunnews.com/nasional/2017 /07/05/data-imigrasi-sepanjang-2017warga-china-paling-banyak-masuk-keindonesia

Boswell, C. (2009). The Political Uses Of Expert Knowledge: Immigration Policy and Social Research. Cambridge University Press.

Djumena, E. (2019). Naik 10,88 Persen, Pekerja Asing Selama 2018 Didominasi dari China. Kompas.Com.

Friedman, M. L. (1975). The Legal System: A Social Science Prespective. Russel Sage Foundation.

Ginting, S. R. (2018). 25 Pekerja Asing Smartfren Ditangkap. Indopos.Co.Id. https://indopos.co.id/read/2018/11/29/1571 41/25-pekerja-asing-smartfren-ditangkap

Iman, S. (2014). Perspektif Imigrasi Dalam Migrasi Manusia. Pustaka Reka Cipta.

Peraturan Menteri Ketenagakerjaan Republik Indonesia Nomor 10 tahun 2018 Tentang Tata Cara Penggunaan Tenaga Kerja Asing, Pub. L. No. 10 Tahun 2018 (2018).

Laoly, Y. (2018). Sambutan Menteri Hukum dan HAM dalam Rangka Refleksi Akhir Tahun 2018 Kementerian Hukum dan HAM Republik Indonesia pada tanggal 27 Desember 2018.

Mamduh, N. (2018). Ombudsman Temukan Masalah Penempatan TKA, Sebagian Jadi Buruh Kasar. Tirto.Id. https://tirto.id/ombudsman-temukanmasalah-penempatan-tka-sebagian-jadiburuh-kasar-cJsu
Moleong, L. J. (2006). Metode Penelitian Kualitatif. PT. Remaja Rosdakarya.

Muhammad, A. (2004). Hukum dan Penelitian Hukum. Citra Aditya Bakti.

Nugroho, A. (2018). TKA dan Masalah Ketenagakerjaan di Indonesia.

Geotimes.Co.Id.

https://geotimes.co.id/opini/tka-danmasalah-ketenagakerjaan-di-indonesia/

Nugroho, T. A. (2018). Peran Intelijen Keimigrasian dalam Rangka Antisipasi Terhadap Potensi Kerawanan yang Ditimbulkan oleh Orang Asing di Wilayah Indonesia. Ilmiah Kebijakan Hukum, 12(3), 278-279.

https://doi.org/http://dx.doi.org/10.30641/k ebijakan.2018.V12.275-293

Petriella, Y. (2019). Aturan Pekerja Asing Dilonggarkan, Jumlah TKA Tahun Ini Ditaksir Naik $20 \%$ Bisnis.Com. https://ekonomi.bisnis.com/read/20190912 /12/1147606/aturan-pekerja-asingdilonggarkan-jumlah-tka-tahun-iniditaksir-naik-20

Putra, D. A. (2018). Ombudsman sebut banyak warga negara asing manfaatkan visa kunjungan untuk bekerja. Merdeka.Com. https://www.merdeka.com/uang/ombudsm an-sebut-banyak-warga-negara-asingmanfaatkan-visa-kunjungan-untukbekerja.html

Rahmat, B. (2016). DPR Soroti Pelanggaran Tenaga Kerja Asing Asal China di Bali. Cnnindonesia.Com.

http://www.cnnindonesia.com/nasional/20 160723231300-20-146597/dpr-sorotipelanggaran-tenaga-kerja-asing-asalchina-di-bali/

Rangkuti, F. (2004). Analisis SWOT Teknik Membedah Kasus Bisnis. PT. Gramedia Pustaka Utama.

Schwartz, W. F. (1998). Justice in Imigration (Vol. 94, Issue 3).

Tanujaya, E. (2010). Era Baru Manajemen. Salemba Empat. 